\title{
Socio-economic determinants of the quality of Irvingia gabonensis harvested by rural dwellers in Sagbama Local Government Area of Bayelsa State, Nigeria
}

\section{Unaeze $\mathrm{HC}^{* 1}$ \& Henry-Unaeze $\mathrm{HN}^{2}$}

1. Department of Agricultural Economics \& Extension, University of Port Harcourt, Port Harcourt, Nigeria

2. Department of Human Nutrition \& Dietetics, Michael Okpara University of Agriculture, Umudike, Abia, Nigeria

\begin{abstract}
The study was carried out to assess the socio-economic determinants of the quantity of Irvingia gabonensis (ogbono) harvested by rural dwellers in Sagbama Local Government Areas of Bayelsa State. A total of sixty respondents were randomly selected from twelve rural communities of the study area. Data were collected using a structured questionnaire and personal interview. Descriptive statistics, multiple regression analysis and a willingness-to-accept compensation model were used in the assessment. The majority of the respondents were female $(63 \%)$. Household size was a significant predictor in determining the quantity of Irvingia gabonensis harvested from the forest. Injuries from knife cuts while opening or picking the fruits, and attacks by wild animals, were the major problems encountered by harvesters. Policies should allow some access to sustainable harvested non-timber forest products, and harvesters should recognize the importance of controls on the levels of harvesting.
\end{abstract}

Keywords: Non-timber forest product, household size, harvesting constraints, over-exploitation

\section{Introduction}

A non-timber forest product (NTFP) as defined by the Centre for International Forestry Research is any product or service other than timber produced in forests; for example, fruits, nuts, vegetables, fish, game, medicinal plants, resins, essence, barks and fibres such as bamboo, rattans and other palms and grasses (Kaspar, 2009). The African mango or Ogbono (Sapindales: Irvingiaceae: Irvingia gabonensis) is just such an NTFP (Nooteboom 1966; Fernando 1995), also called Dika nut, bush mango, wild mango, or (in French) marrguier sauvage (Ladip 1996). The kernels of these species have various local names according to place and language: ogbono (Ibo), apon (Yoruba), mangorone kurmi (Hausa), egbeno (Ijaw), and Okpukpa by some local communities in Sagbama Local Government Area of Bayelsa State, Nigeria. Nigerians distinguish between kernels from I. gabonensis and I. wombolu, referring to the former as ugiri and the latter as ogbono (Dudu 1998). Elsewhere the paste produced from the kernels in Gabon is termed Dika bread (Gabon) and 'etima' (Cameroon) (Ndoye 1997).

Irvingia gabonensis do better in undisturbed lowland tropical forest (Van Dijik 1997). They also adapt better to utisol soils in high rainfall areas such as the southern states of Nigeria, preferring well-drained and wetter conditions (Okafor 1975). The composition of Irvingia gabonensis has been studied and found to have industrial potential. The seed contains $62.2 \% \pm 0.6$ crude fat (Onyeike 1995), making them very good for oil, and $658 \mathrm{mg}$ per g dry wt of lipid (Omogbai 1989). The seeds are usually ground with pestle and mortar on a stone into a paste or cake called "dika" bread, which is used as a soup, stew or sauce additive for flavoring and thickening (Agbor 1994; Leakey \& Newton 1994). The kernels are highly valued for the slimy consistency they produce, but can be roasted to enhance their flavouring effect, with crushed pieces used in frying vegetables (Agbor 1994). The juicy fruit pulp is rich in 
vitamin $\mathrm{C}$, and is widely reported to be consumed as a dessert fruit or snack throughout Western and Central Africa (Ejiofor 1994; Leakey \& Newton 1994) up to 20 at a time (Agbor 1994).

The roots, leaves and bark are used medicinally. The bark is mixed with palm oil for use in the treatment of diarrhoea, and is taken by women to shorten their breast-feeding period. Fresh bark can be used to confer a bitter taste to palm wine if pieces are kept in the wine containers during tapping (Ndoye \& Tchamou 1994). It is also administered for colic and dysentery (Okolo 1995) as well as for hernias, yellow fever and as an antidote to poison (Ayuk 1999). The stems are among several species harvested by tribesmen as 'chewing-stick' fodder for their animals (Mbakwe 1983). Bush mango wood is used by local people for construction (Leakey 1999). The usefulness of Irvingia gabonensis cannot be over-emphasized.

It is common to find (mainly female) members of the rural community engaged in the harvest of Irvingia as a livelihood, to generate revenue. However, NTFPs rarely provide a pathway out of poverty because poor people have limited access to the assets needed to exploit them, such as information, financial capital or credit to invest in harvesting, production, processing, transport and marketing. Getting information and credit depends on appropriate access to transport and communications infrastructure, which are deficient in forest areas. Harvesters also lack political capital to influence policies, social capital or opportunities to work together to increase their bargaining power, and physical capital such as processing equipment, storage facilities and transport infrastructure.

Over the last 30 years, policy makers and conservation NGOs have focused on the sustainable production and commercialization of NTFPs (Barros 2008). Restricting access to forests without compensation may have a negative impact on rural food security and livelihoods, particularly for the poorest households. Policies that allow some access to sustainably harvested products, and where collectors recognize the importance of harvesting controls will be most successful. However, these will be difficult to develop without a greater understanding of the sustainability of the harvests (Sophie 2009). This study therefore investigated the socio-economic determinants of the quantity of Irvingia gabonensis harvested, the methods of harvesting, willingness to-accept compensation measures in order to conserve the trees, methods of processing and the constraints encountered by rural dwellers while harvesting from the forest.

\section{Materials \& Methods}

The study was conducted in Bayelsa State, one of the 36 states of Nigeria. Bayelsa State is divided into eight Local Government Areas, one of which is Sagbama. The inland part of Bayelsa State consists of tropical rainforest, whilst towards the coast the typical Niger Delta environment features many mangrove swamps. With an area of $945 \mathrm{~km}^{2}$ and a population of more than 187000 (2006 census), Sagbama LGA has eighteen rural communities: Sagbama, Odoni, Adagbabiri, Agbere, Asamabinosekeni, Tungbo, Bolouorua, Ndoro, Agorogbeni, Akedi, Kabiama, Ebedebiri, Isoni, Osiama, Toreebeni, Otrofani, Ogobiri and Igbopuluama. Twelve communities and five farmers from each were randomly selected, making a total of sixty respondents.

The Contingent Valuation Method involves the use of sample surveys (questionnaires) to elicit the willingness of respondents to pay for (generally) hypothetical programmes, such as the conservation of forest resources or the damage done by the spill of oil chemicals. The techniques (Ridker 1967; Hammack \& Brown 1974; Cicchetti \& Smith 1973) were used to estimate respondents' willingness-to-accept compensation programmes or measures to conserve forest or other natural resources.

Multiple regression analysis (as described by Koutsoyiannis 1981; Lesschen et al. 2005, Lesschen et al. 2005) was used, with either or both the predictors and response variables 
being log-transformed. The response variable was the quantity of Irvingia harvested per year $(\mathrm{kg})$ per farmer. Predictors were years of farming experience, sex, age, flooding type (excessive, normal), household size, distance to forest $(\mathrm{km})$, and years of formal education.

\section{Results}

Table 1 shows that more than two-thirds of the respondents have been harvesting Irvingia for sale for 6-15 years, more of them women (63\%) than men and more than half were middleaged (41-50 years). Most of the households were small ( $<6$ people). $80 \%$ had had less than 7 years in formal education, and most were poor ( $<400 \mathrm{~K}$ Naira per year). The majority were married.

\begin{tabular}{lclc}
\hline variables & Frequency & variables & Frequency \\
\hline Farming experience (yr) & & Household size & \\
$1-5$ & 4 & $1-5$ & 40 \\
$6-10$ & 20 & $6-10$ & 15 \\
$11-15$ & 23 & $11-15$ & 4 \\
$16-20$ & 8 & $16-20$ & 1 \\
$21-25$ & 3 & Years of formal education & 48 \\
$>25$ & 2 & $1-6$ & 10 \\
Sex & & $7-12$ & 2 \\
Male & 22 & $13-18$ & 0 \\
Female & 38 & $>18$ & \\
Age (years) & & Annual income (K Naira) & 42 \\
$<30$ & 5 & $100-300$ & 15 \\
$31-40$ & 14 & $400-600$ & 3 \\
$41-50$ & 32 & $700-900$ & 0 \\
$>50$ & 9 & $>1000$ & 11 \\
& & Marital status & 49 \\
\hline
\end{tabular}

Table 1: Socio-economic characteristics of Irvingia gabonensis harvesters from field survey in 2013.

The regression analysis showed that the quantity of Irvingia gabonensis harvested was predictable $\left(\mathrm{F}_{7,52}=86.6, \mathrm{p}<0.01, \mathrm{R}^{2}=0.91\right)$. The coefficients demonstrated that two of the predictors were not significant: years of farming experience $(-0.066 \pm 1.1$, n.s.) and flooding type $(4.5 \pm 28.1$, n.s.). The remaining predictors were significant elements of the regression model: sex (men were worse than women, $-241 \pm 39$, $\mathrm{p}<0.01)$; decreasing with age $(-4.8 \pm 1.8$, $\mathrm{p}=0.01)$, increasing with household size $(11.6 \pm 5.2, \mathrm{p}<0.01)$, decreasing with increasing distance to the forest $(-50.4 \pm 12.1, \mathrm{p}<0.01)$ and decreasing with increasing years of formal education $(-32.3 \pm 8.0, \mathrm{p}<0.01)$.

Two thirds (40) of the respondents harvested Irvingia gabonensis though gathering fallen fruits fresh rather than rotten. The majority were willing to accept more than N300,000 to stop over-exploitation (Table 2), but only one person was willing to accept N100,000. Almost two-thirds processed the fruits by removing the seed (ogbono) with a knife, drying them afterwards. The rest gathered the rotten fruits, and then washed and sun-dried or smoke dried them, especially during rainy days; the dried fruit was then opened with an axe or a stone and the seeds removed and further sun-dried for use. The first method is commonly carried out by commercial harvesters, who normally supply to sellers in the retail markets. 


\begin{tabular}{ll}
\hline Amount (Naira) & Frequency \\
\hline 100,000 & 1 \\
150,000 & 2 \\
200,000 & 3 \\
250,000 & 5 \\
300.000 & 11 \\
$>300,000$ & 38 \\
Total & $\mathbf{6 0}$ \\
\hline
\end{tabular}

Table 2: Willingness-to-accept compensatory measures in Naira from field survey in 2013.

\begin{tabular}{lc}
\hline Problem encountered & Frequency \\
\hline Attacks by wild animals (snakes, insects) & 15 \\
Climatic problems(excessive rainfall leading to flooding and damaged seeds) & 10 \\
Injuries sustained from knife/sharp objects while harvesting/ processing & 16 \\
Hitting of fallen mangoes on harvesters during harvesting & 11 \\
Oil spillage resulting in scarcity of forest resources & 2 \\
Militants attack & 1 \\
Head hunters & 2 \\
Forest ownership & 3 \\
Total & $\mathbf{6 0}$ \\
\hline
\end{tabular}

Table 3: Distribution of respondents according to problems encountered while harvesting Irvinga

About a quarter of the respondents reported that their major constraint during harvesting and processing them into the final kernels was being cut by their matchet/knife while opening the fruits or picking out the seeds. Another $25 \%$ said that theirs was being bitten by snakes or insects while harvesting, while eleven people mentioned being hit on the head by falling mangoes, and a further ten mentioned excess rainfall and flooding as their major constraint. Minor issues were forest ownership, oil spillage, head hunters and attacks by militants.

\section{Discussion}

The long years of experience of some of the respondents show that they obtain their livelihoods from harvesting Irvingia gabonensis. More women were involved, just as Sophie (2009) found. The age range of majority of the harvesters implied that they were still active and could withstand the drudgery involved in harvesting. Large families did better at harvesting because children (cheap labour!) are needed to assist their parents in the business of harvesting and processing (cf. Awotide et al. 2011). Schreckenberg et al. (2006) reported that the harvesting and marketing of NTFPs have been noted to support large households in rural areas during scarcity. The harvesters in this study area clearly tend not to be educated.

Since about five kernels of Irvingia sell for N50 or more in the market, the annual income of the respondents indicate that this NTFP is in high demand and very expensive. The insignificant effect of farming experience on the harvest quantity could be because weather conditions influence it greatly. Men were worse at collecting Irwingia fruits probably because they have other jobs as well, and harvesting fruits can be deemed to be women's work. Age had a negative effect on harvest quantity because of the drudgery involved. The negative influence of years of formal education is consistent with a priori expectation because more highly educated people shift their attention to other income-generating ventures like white collar jobs or other business activities.

Most respondents were willing to stop over-exploiting Irvingia gabonensis if they were given compensatory measures, as Sophie (2009) found. Graphical representation of willingness-to-accept compensation showed that as long as compensation keeps on increasing, 
the more eagerly the respondents would be in curtailing their over-exploitative tendencies on the forest resources of the study area.

The fact that majority of the respondents had matchet/knife cuts as their main constraint is not surprising. This problem is mostly encountered during the rainy season, and coincidentally also excessive rainfall affects the quality of the ogbono seeds once they are soaked. The list of the constraints of harvesting Irvingia is not similar to those of Nwauzor (2001). The few respondents that had militant attack as their major problem was as a result of the fact that the federal government carried out an amnesty programme for militants: forests in this region are now safe from such problems.

Based on the above research findings, we recommend that developing Irvingia gabonensis market chains will require investing in other areas such as access to credit, transport and training in sustainable forest management, including the collection, processing and trade of forest resources. Scientific evidence needs to merge with traditional knowledge to provide a better understanding of the socio-economic and ecological environments in which Irvingia gabonensis products are used. Women and men play different roles in NTFP market chains and benefit in different ways: a gendered analysis is important in supporting households dependent on forest resources. Policies that allow some access to sustainably harvested products, and where harvesters recognize the importance of controls on harvesting are more likely to be successful. Government should create policies and institutions that facilitate local partnerships between communities and private enterprises, and ensure that trade and use of forest resources are monitored. It is important that harvester of NTFPs should also have access to more reliable and steady sources of income, such as other agricultural and off-farm activities, to diversify their subsistence and income sources and thus increase their livelihood security.

\section{References}

Agbor LON (1994) Marketing trends and potentials for Irvingia gabonensis products in Nigeria. ICRAF-IITA Conference on Irvingia gabonensis Ibadan, Nigeria May, 1994.

Ayuk ET (1999) Uses, management and economic potential of Irvingia gabonensis in the humid lowlands of Cameroon. Forest Ecology and Management.

Awotide BA, Diagne A, Awoyemi TT \& Ojehomon VET (2011) Household endowment and poverty reduction in rural Nigeria: evidence from rice farming households. Agricultural Journal 6(5): 274-284

Barroso M (2009) Are NTFPs a way out of poverty? id21 Forestry Insights May 2009, Issue 77. Institute of Developmental Studies Sussex.

Cicchetti CJ \& Smith VK (1973) Congestion, quality deterioration and optimal use: wilderness recreation in the Spanish Peaks Primitive Area. Social Science Research 2: 15-30

Dudu PO (1998) Attractancy of diethyl ether extract of Arachis hypogaea (Linnaeus) (Papilionaceae), Citrullas lanatus (Thunberg) (Cucurbitaceae) and Irvinga gabonensis var. excelsa (Baillon) (Irvingiaceae) to Oryzaephilus mercator (Fauvel) (Coleoptera: Silvanidae). Journal of Stored Products Research 34: 237-241

Ejiofor MAN (1994) Developing improved methods of processing and utilization of kernels of Irvingia gabonensis (var, gabonensis and var. excelsa). International Tree Crops Journal 4: 283-290

Fernando ES (1995) Simaroubaceae, an artificial construct: evidence from rbcl sequence variation. American Journal of Botany 82: 92-103

Hammack J \& Gardner B (1974) Waterfowl and wetlands: toward bio-economic analysis. Johns Hopkins University Press, Baltimore

Kaspar S (2009) What are NTFPs? id21 Forestry Insights May 2009 Issue 77. Institute of Developmental Studies Sussex

Koutsoyiannis A (1981) Theory of econometrics. McMillian Education Ltd., Basingtoke, Hamphire.

Ladip DO (1996) Domestication of the Bush Mango (Irvinga sp.): some exploitable intraspecific variation in West and Central Africa. FAO, Rome Italy.

Leakey R \& Newton A (1994) Domestication of tropical trees for timber and non-timber products. MAB Digest, 17: 67-68 (Unesco, Paris)

Lesschen JP, Verburg PH \& Staal SJ (2005) Statistical methods for analyzing the spatial dimension of changes in land use and farming systems. Lucc Report Series International Livestock Research Institute. Nairobi, Kenya

Mbakwe RC (1983) A special form of wood utilization in Africa and its effects on the forest. Forstarchiv 54: 228 
Ndoye 0 (1997) Non-wood forest product markets and potential forest resource degradation in Central Africa: the role of research in providing a balance of welfare improvement and forest conservation. CARPE: Limbe NonWood Forest Products Workshop.

Ndoye 0 \& Tchamou N (1994) Utilization and marketing trends for Irvingia gabonensis products in Cameroon. ICRAF-IITA Conference on Irvingia gabonensis, Ibadan, Nigeria

Nooteboom HP (1966) Flavonols, leucoantheocyanins, cinnamic acids and alkaloids in dried leaves of some Asiatic and Malesian Simaroubaceae. Bumea 14: 309-315

Nwauzor EC (2001) Nematode problems and solutions of root and tubercrops in Nigeria. In : Akoroda MO \& Ngeve JM (eds). Proceedings of the 7th Triennial Symposium of the International Society for Tropical Root Crops (ISTRC). Cotonou, Oct.11-17, 1998: 545-552

Okafor JC (1975) Varietal delimitation in Irvingia gabonensis (lrvingiaceae). Bulletin du Jardin Botanique National de Belgique 45: 21 1-221

Okolo CO (1995) Analysis of effect of Irvingia gabonensis stem bark extract. Journal of Ethnopharmacology 45: $125-129$

Omogbai FE (1989) Lipid composition of tropical seeds used in the Nigerian diet. Journal of the Science of Food \& Agriculture 50: 253-255

Onyeike EN (1995) Effect of heat-treatment and defeating on the proximate composition of some Nigerian local soup thickeners. Food Chemistry 53: 173-175

Ridker R (1967) The economic cost of air pollution. Praegler, New York.

Schreckenberg K, Marshall E \& Willem te Velde D (2006) NTFP commercialization and the rural poor: more than a safety net? In: Marshall E, Schreckenberg K \& Newton AC (eds). Commercialization of non-timber forest products: factors influencing success, lessons learned from Mexico and Bolivia, and policy implications for decision-makers. UNEP World Conservation Monitoring Centre, Cambridge, UK. 71-76

Slater R (2008) Feeding poor people while the climate changes. id21 Natural Resources Highlights. Institute of Developmental Studies, Sussex 6(4): 1

Sophie A (2009) Wildlife products and forest livelihoods. id21 Forestry Insights Institute of Developmental Studies Sussex 77(5): 5

Van Dijk JFW (1997) Non-timber forest product in the Fipindi Akom II region, Cameroon: a socio-economic and ecological assessment. Tropenbos-Cameroon Series No. 1, Netherlands.

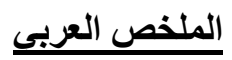

الملخص 